\title{
Ambiances
}

anbiances Environnement sensible, architecture et espace urbain Varia | 2018

\section{When Durga Strikes. The Affective Space of Kolkata's Holy Festival}

Quand Durga débarque. L'espace affectif du Festival Sacré de Kolkata.

\section{Federico De Matteis}

\section{OpenEdition}

\section{Journals}

Electronic version

URL: http://journals.openedition.org/ambiances/1467

DOI: 10.4000/ambiances. 1467

ISSN: 2266-839X

\section{Publisher:}

Direction Générale des Patrimoines - DAPA - MCC, UMR 1563 - Ambiances Architectures Urbanités (AAU)

\section{Electronic reference}

Federico De Matteis, «When Durga Strikes. The Affective Space of Kolkata's Holy Festival », Ambiances [Online], Varia, Online since 18 November 2018, connection on 21 April 2019. URL : http:// journals.openedition.org/ambiances/1467 ; DOI : 10.4000/ambiances. 1467

This text was automatically generated on 21 April 2019

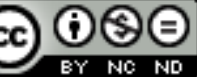

Ambiances is licensed under a Creative Commons Attribution-NonCommercial-NoDerivatives 4.0

International License. 


\title{
When Durga Strikes. The Affective Space of Kolkata's Holy Festival
}

Quand Durga débarque. L'espace affectif du Festival Sacré de Kolkata.

\author{
Federico De Matteis
}

1 Each year, during the Hindu month of ashvin, between September and October, cities in the eastern part of the Indian subcontinent are literally taken over by Durga puja, the solemn celebration of the Goddess Durga. It is a nine-night festival of particular significance to Bengali people, an occasion for religious worship, but also for annual family reunions, traditionally intended for the return of married women to their ancestral home. During the first nine nights of waxing new moon of the month, many Indian cities are deeply transformed: the celebrations are not performed in temples, but in temporary ritual sites (pujalaya) sheltered within lightweight marquees built with bamboo and cloth (pandal). More than western cities during the Christmas season, urban areas are transfigured by the presence of the pandals, the round-the-clock rituals including prayers, music and dance, and the festive mood that pervades every corner.

2 With this paper, I intend to describe the transformation of Kolkata during the days of Durga puja under the lens of the affective space that the event generates. The West Bengal capital stages one of the largest and most spectacular celebrations, and is considered the place of origin of its modern-day form (Bhattacharya, 2007). What takes place in the city during the festival is not the result of a centralized design, but rather of a collective initiative that is informally regulated by both traditional religious worship and contemporary urban practices (Ghosh, 2009). The result of this enterprise transports the city's space into an exceptional state for the entire duration of the event, one that profoundly strikes Kolkatans and visitors alike.

3 As a religious festival, Durga puja is an event that shares many features with other sacred celebrations, both in India and elsewhere. Its reliance on temporary architectural objects is in some ways also similar to many lay festivals, such as rock concerts or art events, e.g. Burning Man, Roskilde Festival, or Coachella. Yet, what makes Durga puja a one-of-a-kind event is the strict collaboration of permanent and temporary architectural objects, where 
the latter become supervenient as if to complement the existing city's physical structure. Other religious festivals, such as the colossal Maha Kumbh Mela, held every 12 years in Allahabad, draw in far more pilgrims than Durga puja, spawning gigantic "instant cities"; however, there is here a limited relation between the event's architecture and ordinary urban space. What happens in Kolkata is a transformation that acts through cooperation between the permanent and the temporary, somehow representing the very character of the Goddess's descent to the human world, which introduces a "special" time for ritual renovation.

4 My description of Durga puja is based on the visit of the 2015 festival. I will focus on several elements that are crucial in the production of the specific atmosphere that I experienced in Kolkata's public spaces. These include the architectural objects set up for the celebrations in their relationship with the existing urban space; the organization of the pandals' interiors, and the nature of the corporeal communication established between the worshippers and the ceremonial statues during the rites; the ritual processions at the puja's conclusion on the river Hooghly's ceremonial ghats. This description will be preceded by a general introduction of the concept of affective spaces in the city and followed by a conclusion discussing the significance of Durga puja as a form of living heritage.

\section{Affective spaces}

5 Cities have their style: a peculiar character that distinguishes one from the other, allowing inhabitants and visitors to describe what it is like to be there. This character is hinged to the material constitution and configuration of a city, but it exceeds it by including a multitude of immaterial, fleeting elements that are not permanently present, yet deeply influence the way subjects experience urban space. While buildings, streets, sidewalks, trees, billboards and the like permanently populate physical space, sounds, smells, wind, or light come and go, and the variable presence of human subjects produces an intense communicative dynamic that contributes to the definition of an emotional tone.

6 The notion that space catalyzes the individuals' emotional response is today shared by many disciplines, such as architecture, philosophy, geography, anthropology and urban studies. In recent years, this has led to a conflagration of models stressing different aspects of an overly complex dynamic, involving both the environment in its variable configurations and the human subject that encounters it in his specific disposition. To make things more complicated, the affective dimension - especially in the urban realm is hardly ever encountered by a single individual, and much more often by groups of people that experience them collectively, on the basis of complex interactions (Scheler, 1923).

7 The relationships between affects and space is a particularly complex conundrum. Several authors underline the intrinsic vagueness of concepts such as atmosphere, today widely adopted to describe the character of urban and architectural settings. Ben Anderson defines affective atmospheres as "collective affects that are simultaneously indeterminate and determinate", noting their ambivalence of being real phenomena that are not necessarily of a sensible nature, "associated with the uncertain, disordered, shifting and contingent - that which never quite achieves the stability of form" (2009, p. 78). Despite their ambiguity, however, affective atmospheres may be objective, in the sense that they become supra-personal, exerting their force on all those that are 
surrounded by them. Matthew Gandy equally laments the vagueness and indeterminacy of atmosphere as an ontological notion, claiming that it inhibits the possibility to "theorize the relationship between space and subjectivity" (2017, p. 358).

In New phenomenology, where the contemporary notion of atmosphere first originated through Hermann Schmitz's work, vagueness as a fundamental perceptual condition is fully espoused as the expression of a specific model of space (Rauh, 2017, p. 12). What Schmitz terms "space of feeling" - Gefühlsraum - entirely escapes geometrical definition, in its condition of being devoid of surfaces (1969, p. 185). However, this space is all but empty, being populated by a myriad of "half-entities like the wind, voices, the sense of overpowering gravity, electric shocks, pain, melodies [...]. The duration of half-entities can be interrupted" (Schmitz et al., 2011, p. 256). Emotions, in their being spatially diffused, are also half-entities that "immediately corporeally and affectively involve the conscious subject as modes of influence indistinguishable from causes" (ibid.). The ontological status of these entities does not question their existence: their intrinsic vagueness is connected to their impermanence, and to their spatial indeterminacy derived from being devoid of surfaces, the two qualities that distinguish them from full entities. Schmitz adopts the acoustic model as an analogy to clarify the spatial character of feelings as atmospheres, thereby elucidating their agent capacity despite a positional indeterminacy (1969, p. 194).

9 For Schmitz, as in the earlier phenomenological tradition, the notion of lived body (Leib) is central to the understanding of the subject's presence in space. This presence is articulated through the constant interplay and alternance of corporeal stirrings, primarily the expansion and contraction that the subject experiences as an expression of vital drive (2011, p. 15). Gernot Böhme clarifies the role of the lived body through the concept of space of bodily presence (2017, p. 91), contrasting from both classic notions of physical space (spatium) and place (topos). It represents the space as felt by the experiencing subject, extending beyond the material constitution and including the emotions that are atmospherically poured into the environment. In this sense, dynamically enacted perception feeds into a loop with the emotional response of subjects and their movement, in the twofold acceptation of displacement through space and corporeal stirrings (Schmitz, 2011, p. 4; De Matteis, 2018, p. 442).

10 Atmospheric perception is inherently pre-reflective, hinging on immediate corporeal responses that orient any interpretive act on the side of the subject. It is an aesthesis of first impressions (Griffero, 2014, p. 29), a brief yet fundamental moment when the subject connects with whatever is emerging from the surrounding environment. Traditionally considered negligible, the emotional responses that the subject experiences are a primary source of knowledge about the world, one that is central and hardly prone to falsification, far more transversal than rationally determined interpretations, due to their stable engagement with corporeality. This does not mean that the subjects' response to recurring spatial conditions is always the same, nor that there is an implicit scheme bound to a cause-effect principle. Spatial situations are always complex, and their repetition may be limited to the salience of some elements over others, possibly connected to the individual's specificity and perceptual "style" (Wober, 1966).

11 Another notion that has gained traction in recent years, especially in relation to the urban sphere, is that of ambiance. The term is today used to describe the contingent manifestation of the urban environment, emphasizing "the situated, the built and the social dimensions of sensory experience" (Thibaud, 2015). In this sense, "the tangible 
ambiance is co-determined by the physical milieu, by perceived phenomena, but also by social behaviours such as incorporation, actualisation and by the reconfiguration of the perceptible potential of the place travelled through" (Griffero, 2013, p. 3). The richness of this model is connected to its ability to render the feeling of the city emerging as a unified whole, unrestrained by the harsh analytical tomography often reducing the description of urban space to a cadaveric inspection that focuses on individual parts, while neglecting the connections between them.

The notion of affective space that I adopt here is directly derived from the neophenomenological concepts of atmosphere and space of bodily presence, however with a stronger emphasis on some recurring situational characters of the built environment, envisaged to provide a clearer description that observes the architectural and urban characters of the account. The central proposition is that spatial arrangements and organizations elicit fundamental, pre-noetic responses from most subjects; these responses are largely transversal, and only in part determined by entrainment. Their quasi-objectivity relies on a common corporeal root that underlies and precedes culture and beliefs (Sheets-Johnstone, 2011, p. 309), thus facilitating the constancy of response across variable contexts and conditions. Space so conceived is non-representational, in its articulation through corporeal practices that sum the biological with the cultural embodiment of subjects (Thrift, 2008, p. 8).

\section{Images of the city}

13 The conceptual richness of the neo-phenomenological space model implies a multiplicity of questions related to its application in the production of accounts of phenomena and situations. The rigorously subjective stance called into the foreground by the centrality of the lived body, and the rejection of quantitative data analysis restrain such descriptions to first- or second-person accounts, which are true to the fundamental consideration that lived-space conditions may only be apprehended from within: "we may be part of the ambiance or we may feel it, but we cannot contemplate or observe it from a distance" (Thibaud, 2011, p. 205). As is the case with all direct accounts, the very analytical instrument - in this case the observer - is inevitably biased by his own enculturation and disposition, and no description may prescind from defining the specificity of the observer along with the studied situation. An affective space is not exclusively connected to the materiality of the physical environment; the subject's response is always situated, so that the nature and quality of this response can only be understood in terms of the relationship between the subject itself and the situation.

In several cases, the neo-phenomenological approach has proven useful in the production of accounts that enrich the observation of phenomena through the lenses of atmospheres, lived body, suggestions of movement and others, as derived from Schmitz's work. In describing Mauritian Muslim devotional music, Eisenlohr leverages on the concept of atmosphere to underscore "the intermingling of sound and the felt-body", reaching beyond the notion of soundscape as a three-dimensional auditory space, preferring a model based on surface-less space (Eisenlohr, 2018, p. 39). This same central concept, subtending all considerations on the spatial qualities of atmospheres, is used by Runkel to discuss the phenomena of solidary encorporation that animate crowds as forms of corporeal communication (Runkel, 2018, p. 6), a dynamic that is strictly related to urban settings - and also plays a significant role in the Durga puja festival. 

adopted to produce accounts more closely related to urban ambiances, often in combination with insight derived from architectural critics connected to the phenomenological tradition, such as Rasmussen, Pallasmaa etc. In this sense, Kiib et al. devise a description of the Danish Roskilde music festival that merges the objective analysis of the temporary buildings with the second-person account of the participants (Kiib et al., 2017). The result is a vivid rendering of the festival, providing a feeling of the affective atmosphere that is installed through the temporary architecture and the attendees, but also addresses the political agenda emerging from this mass event.

Accounts that are centered around the relationship between subjects and the built environment often suffer from the difficulty of bridging the physical dimension of space and its immaterial constituents, in terms of atmospheric presences, collective encorporations, ecstasies and other notions adopted from contemporary phenomenology. The concept of affective space, however, relies on the constancy or similarity of corporeal responses experienced by subjects who encounter typical spatial arrangements, that serve as scaffolds for the emergence of the immaterial situational conditions. The description of Kolkata's Durga festival in the following pages thus aims to illustrate how the physical features of the transformed urban setting sustain its atmospheric character, while not directly nor entirely determining it. In this sense, it could be qualified as a thick description, as theorized by Gilbert Ryle (1968) and elaborated by Clifford Geertz (1973, p. 3 ff.): an account that relies on the centrality of phenomena, but inscribes them within a horizon of sense, by illustrating the context articulating the reported events. Context is here to be understood in both a general cultural and a more specifically architectural sense, as the material support of the situation taking place in the public spaces of Kolkata. Therefore, if the account is the auto-ethnographic report of the author, thereby depending on my own subjective culture and contingent corporeal disposition, the objectivization of the narrative relies on the typicality and constancy of the specific architectural arrangements of the festival.

\section{Rituals for the Great Goddess}

I am the Queen, the gatherer-up of treasures / most thoughtful, first of those who merit worship. / Thus gods have established me in many places / with many homes to enter and abide in. (Rigveda, Devi Sukta, 10.125)

The cult of mahadevi (great Goddess) Durga is central in Bengali Hinduism, to the extent that since the early $19^{\text {th }}$ century, the religious aspect of the celebration has merged with the rise of a nationalist movement under the British Raj (Bhattacharya, 2007, p. 924). The regional connotation of the rite derives from the pre-Brahminic origin of the Goddess, whose incorporation into the Hindu pantheon of divinities only began around the $6^{\text {th }}$ century AD. This accounts for the vast popularity of the cult in the Eastern part of the Indian subcontinent, where she is revered in a syncretic form binding her original character with shakti, the classic Vedic notion of feminine divine energy (Rodrigues, 2003, p. 15; Bhattacharya, 2007, p. 925).

Durga's myth is narrated in several scriptures that exalt her demon-slaying feats (Rodrigues, 2003, p. 50). The central storyline that is staged in the clay statues produced for the annual festival begins with the shape-shifting buffalo-demon Mahisa, who tricks the gods into granting him a near immortality - he could only be slain by a woman. The 
demon challenges the gods and defeats them; to fight back, they combine their energy in the form of light streaming out of their heads and materializing Durga, a woman of supreme beauty. Armed with a panoply of divine weapons and riding a lion or tiger, Durga approaches Mahisa and, through wit, charm and brute force, eventually slays him in a dramatic showdown. In the traditional puja representation, Durga is shown in the crucial moment of the fight, piercing the beheaded demon with a spear, while her two sons Kartikeya and Ganesa and her two daughters Lakshmi and Saraswati stand supportively by her side.

Illustration 1: Divine family portrait: lion-mounted Durga in the center slays buffalo-demon Mahisa, while her children Ganesa, Lakshmi, Saraswati and Kartikeya stand by.

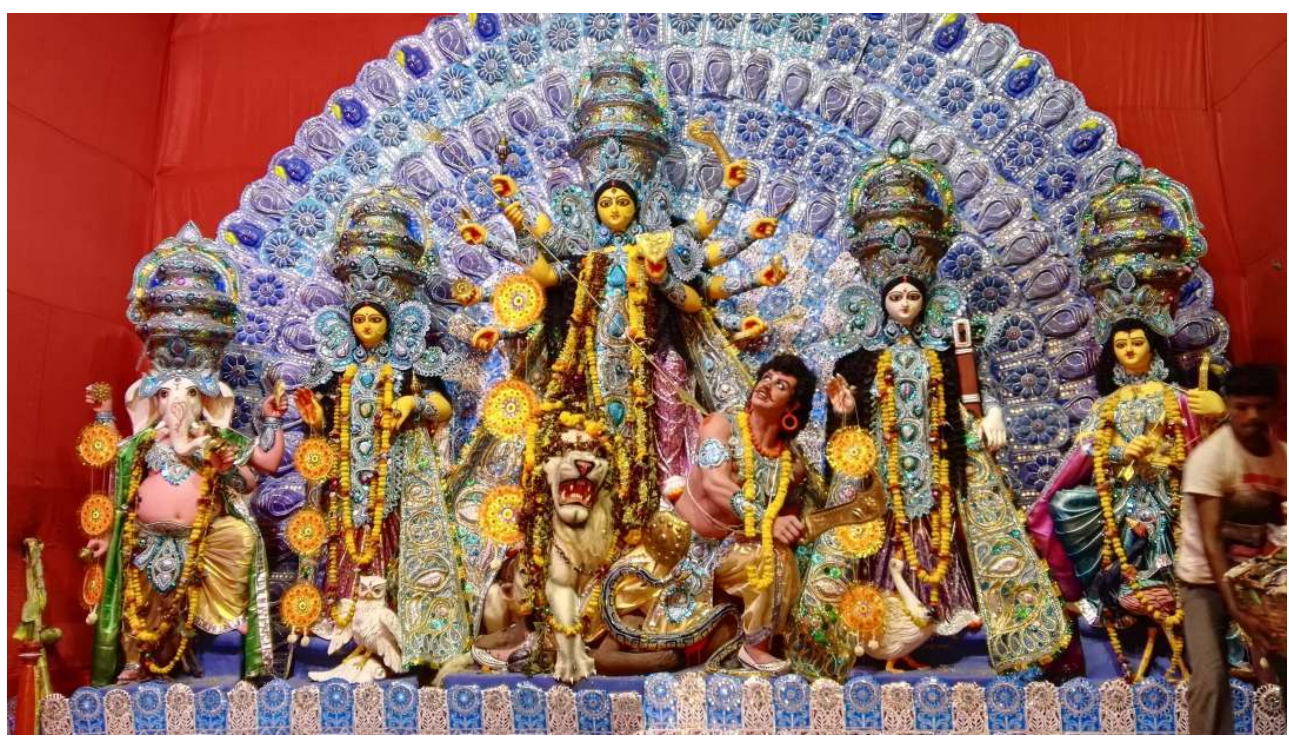

Source and copyright: @ Federico De Matteis. Hindu pantheon. Her abode is the sacred Kailash mountain, from where she is summoned each autumn to bestow her protection upon the world. She is a markedly feminine divinity, in her twofold nature of $M a$ (mother of gods) and of virgin warrior, inherited from her mountain-dwelling pre-Vedic ancestress (Bhattacharya, 2007, p. 925). This nature of ideal mother/daughter connotates the entire Durga puja celebration, originally performed in wealthy Bengali homes that would, for the occasion, host the family's married daughters who, just like the Goddess herself, reside in their husbands' abodes. The domestic character of the festival, sustained by wide family reunions throughout India and the Bengali diaspora, make Durga puja a central social ritual comparable to Christmas or Thanksgiving. During these days, ancestral homes are filled with the voices and traditional clothing of returning daughters with their husbands and children, and the "sense of Durga's presence [is] inseparable from the energy and atmosphere generated by the women gathered in the household" (Rodrigues, 2003, p. 28). Arrivals, reunions, departures of family members provide an emotional background that underscores and mirrors the narrative of the invocation and farewell to Durga during the celebration.

In both domestic and public settings, the puja consists in an articulated ritual that lasts five days within the nine-night festival (Rodrigues, 2003, p. 2). At the center of the celebration is the purohita (an initiated priest), who must be well trained in the 
performance of this central devotional act of Hindu religion. Family and community members partake in the many stages of the puja with tasks that are variously overseen by the leading priest, such as the preparation of food offerings, a duty traditionally carried out by women. During the course of the puja, the purohita invokes the Goddess and temporarily hosts her within his own body, before transferring her to the clay statue, where she resides until she is bid farewell in the final act of worship. The celebration peaks at the juncture of the eighth and ninth night, with the Sandhi puja, a devotional offering that in earlier times included the sacrifice of a goat or buffalo, to satisfy the Goddess's fearful Chamunda or Kali form (Rodrigues, 2003, p. 59).

One feature of Durga puja that distinguishes it from ordinary temple devotion and from many other Hindu celebrations is its locational nature. Active Hindu temples are believed to host the living presence of the divinity, signaled by flags and banners adorning the towering shikhara: Durga herself has temples solely dedicated to her cult. To carry out her annual celebration, however, "the Goddess is invoked into places where she is not normally available and where she will be worshipped only during the course of the festival" (Rodrigues, 2003, p. 50). This sacred occupation of space is ritually established by the purohita, who sanctifies a temporary place of worship, the pujalaya, where the Goddess will eventually be installed once she is awakened and summoned to the earthly world (Rodrigues, 2003, p. 35).

The site's purification is preceded by its cleaning and decorating, and by the erection of the pandal. This cordoned-off space is then identified by the ritualist through the dig bandhana (restraining of directions), that implies the creation of "a virtual "black hole" [... ] where there is no time, no space, and no direction" (Rodrigues, 2003, p. 79). The archetypal religious act of delimiting a sacred space, that may be both permanent or cyclically repeated as symbol of cosmic renewal, implies that "the mythical event [becomes] present once again" (Eliade, 1987, p. 77). Therefore, during the festival Goddess Durga's presence is felt throughout the sacred territory instituted by the constellation of ritual sites, claiming to the divine domain otherwise profane parking lots, empty plots, parks, squares, alleys or whatever available space can be found.

The multiplication of ceremonial pandals during the festival establishes the peculiar urban character of Kolkata's Durga puja. In fact, the contemporary form of this event dates to the $19^{\text {th }}$ century, and develops in parallel with the growth of Calcutta as the capital of the British Raj. The earliest records of celebrations lead to Bengali zamindars (landowners) who held family rites in the late $16^{\text {th }}$ and early $17^{\text {th }}$ centuries, with the first public puja taking place at the end of the $18^{\text {th }}$ century (Bhattacharya, 2007, p. 933). The region's troubled history in that period sees struggles between Muslim and Hindu power groups, along with increasing influence of the East India Company: the translation of the rite from the domestic interior to the public milieu intended to showcase the superiority of Hindu communities over the other contenders. But the most significant shift occurs in the 1920's, when local associations begin organizing pujas that are no longer sponsored by wealthy families: the sarbajanin pujas, originally performed in Kolkata's northern Baghbazar area, are hosted by neighborhood clubs that raise funds from residents to stage celebrations that identify micro-communities (Ghosh, 2009, p. 8).

Over the last century, Durga Puja has thus evolved into an urban practice epitomizing the idea of public space as characterized by "the total dynamic - human and non-human - of a public setting, [where] the collective impulses of public space are the result of precognitive and tacit human response to a condition of 'situated multiplicity', the thrown 
togetherness of bodies, mass and matter, and of many uses and needs in a shared physical space" (Amin, 2008, p. 8). This collective, partially informal and pre-reflective use of space on behalf of the festive crowd accounts for both the puja's atmosphere and for no small dose of conflict, emerging from the competition between neighboring communities and their respective pandals, and from the temporary, at times scarcely tolerated, infringement of norms related to the occupation of public space that the erection of the ceremonial marquees purports. As some of the pandals occupy free spaces that are normally used by the community - parking lots, plazas or even streets, at times their position can affect the smooth operation of urban spaces that throughout the year are characterized by high human densities and vitalities. Yet, in the face of emerging contrapositions, the over-arching authority of Durga herself is sometimes invoked to quell conflict, provided that the pandals are erected to honor her and thus provide a "greater good" to the community as a whole (Ghosh, 2009, p. 13).

As any other major religious event around the world, Kolkata's Durga puja is witnessing an increase of its commercial aspect, with the mundane overshadowing the religious. Visitors and tourists today are lured more by the folk festival than by the actual sacred rites, with a subsequent rise in competition between local communities to attract crowds that can justify the financial contribution by major corporate sponsors (Ghosh, 2009, p. 17). Over the years, pandals have significantly grown in size and flamboyance, with spectacular architectural feats set up with nimble bamboo structures and elaborate artisanal decorations, sometimes meant to evocate far-away places - from Kerala to the Trevi fountain (Ghosh, 2009, p. 10). Folk music and dance shows are staged to attract visitors; local companies assign prizes for the best pandals, ritual statues, devotional drummers etc.; festive street lighting brightens the soft nights of Kolkata's post-monsoon season. The stage is set for the arrival of the Goddess.

\section{When the numinous pervades the city}

The sacred is neither public nor private, though it qualifies both immeasurably by engaging the mythic dimension inherent in the non-manifest. Mankind has always been fascinated by the invisible, the unknown, the unknowable. (Correa, 2011)

The extent to which Kolkata's puja atmosphere can be perceived as more religious than that of a lay city-wide festival is an open question. Regardless of this issue, however, it is a matter of fact that the celebration of Durga brings about a radical temporary transformation in Kolkata's urban space. In some neighborhoods, pandals are erected in close proximity to each other, with up to five in a single urban block, and the overall number of public pujas in the city exceeds 1000 (Ghosh, 2009, p. 8). 
Illustration 2: Durga in the city: 2017 Kolkata Police map of ceremonial pandals.

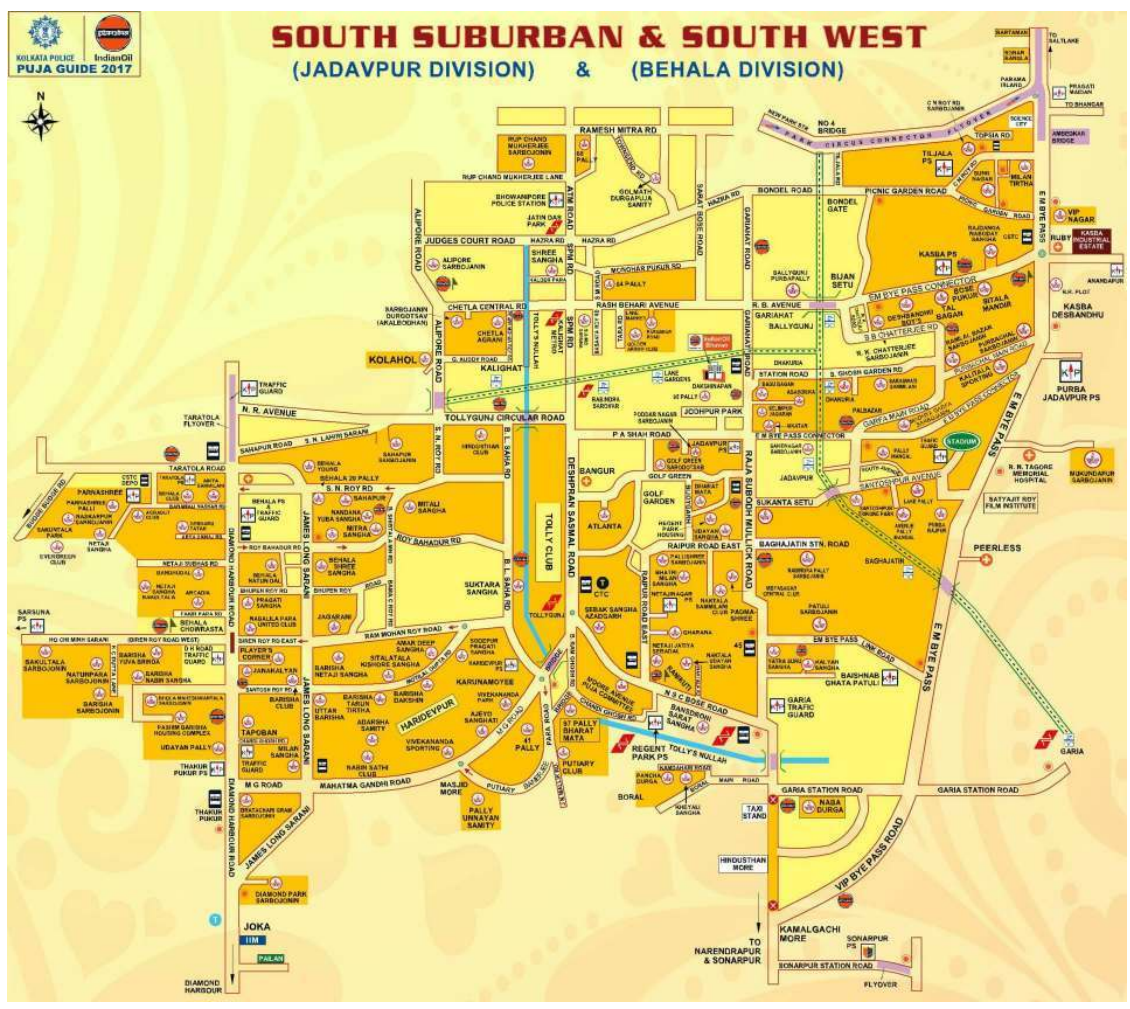

Source and copyright: @ Kolkata Police website

The availability of space in a city that, according to the census, has a population density over 24,000 inhabitants $/ \mathrm{km}^{2}$ is no trivial issue, so pandals sometimes act as infills of nearimpossible spaces such as narrow alleys. 
Illustration 3: Pandal fit into a narrow alley in the Kalighat neighborhood.
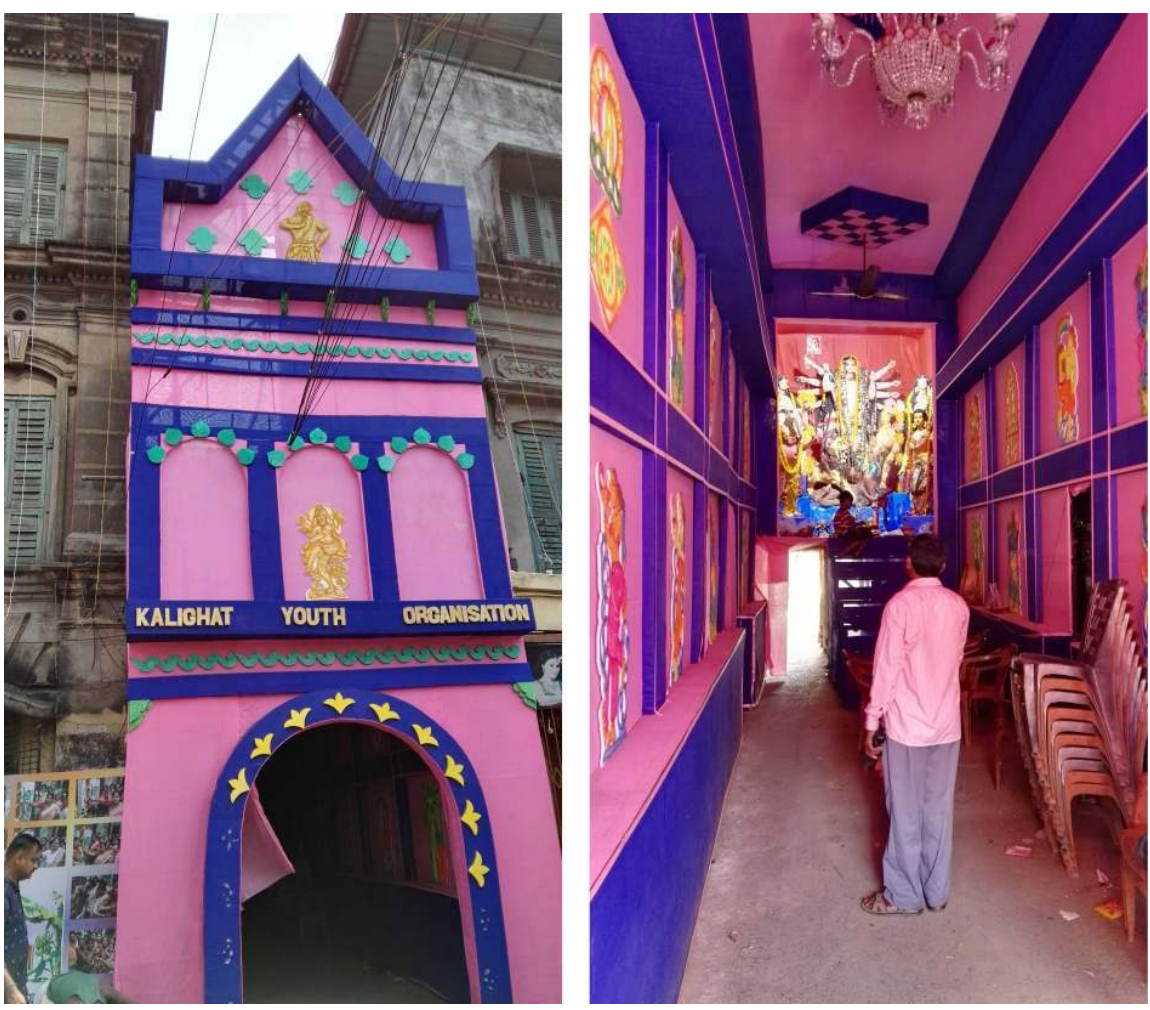

Source and copyright: () Federico De Matteis.

In this case, the tiny temples preserve the possibility of passage granting access to temporarily occluded buildings at the rear.

Pandals are skilfully crafted with elaborate lashed bamboo structures, a traditional craft extensively used in West Bengal to produce temporary buildings to shelter a wide array of events such as weddings or parties. 
Illustration 4: Pandal under construction in Howrah: workers mount the laced bamboo structure.

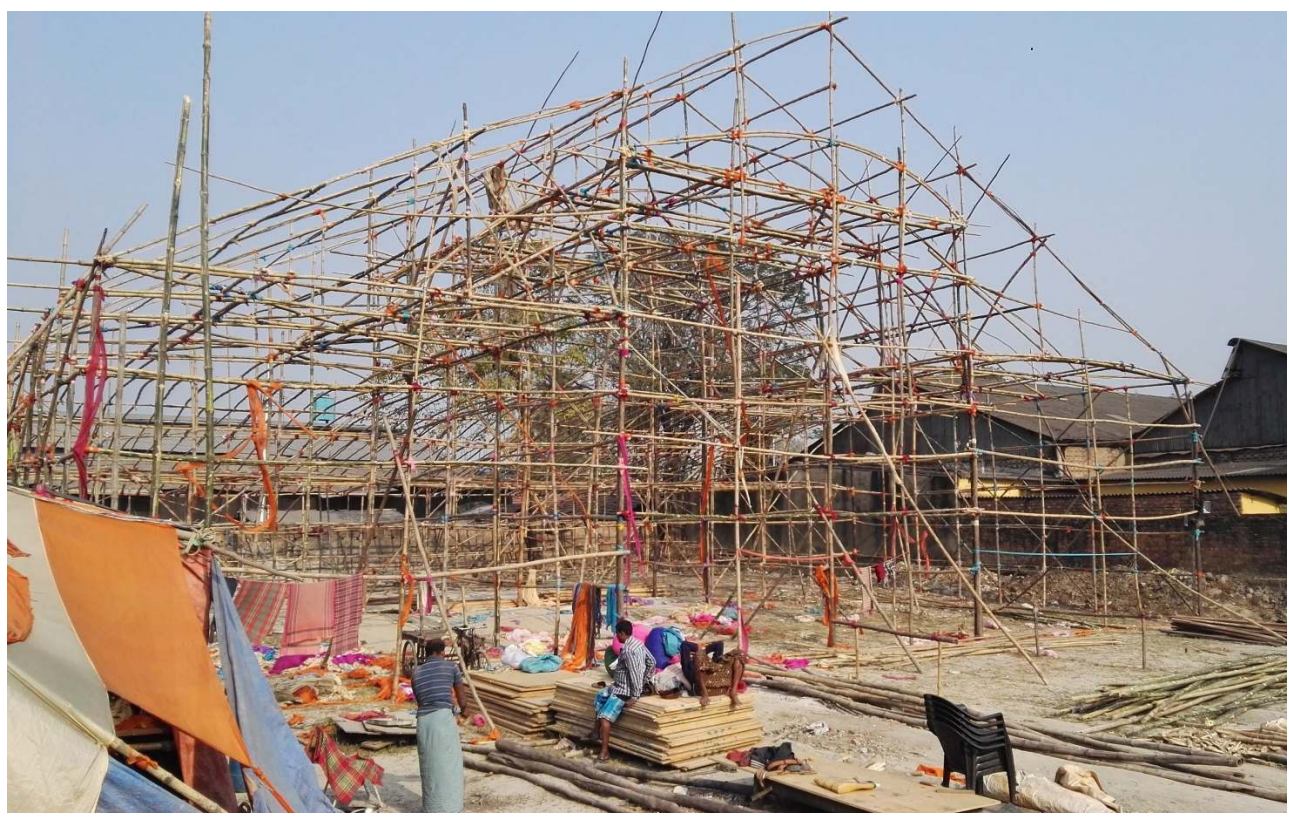

Source and copyright: (๖ Federico De Matteis.

The light structure is then covered with cloth, painted canvas, tarpaulin, paper and further decorated with a wide array of techniques sourced locally or from other Indian regions, such as pottery, papier-mâché, stucco, or straw.

Illustration 5: Straw decorations in pandals.
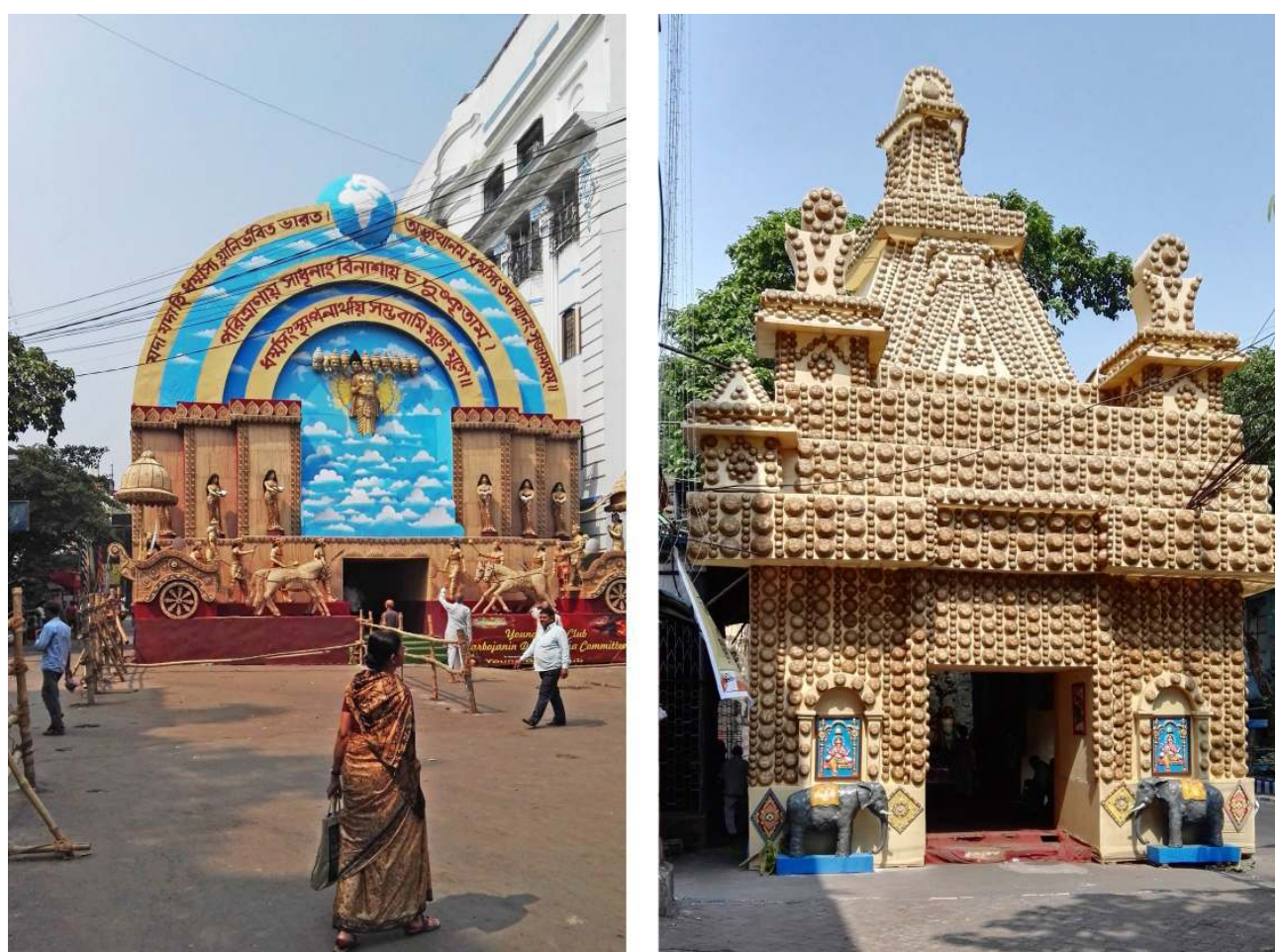

Source and copyright: (C) Federico De Matteis. 
31 The architectural configuration of the tents is very diverse, with frequent references to Hindu temples, vernacular architecture from various areas, Indo-Saracenic elements or the classic heritage of colonial buildings in Kolkata.

Illustration 6: Vernacular elements in the pandals' architecture.
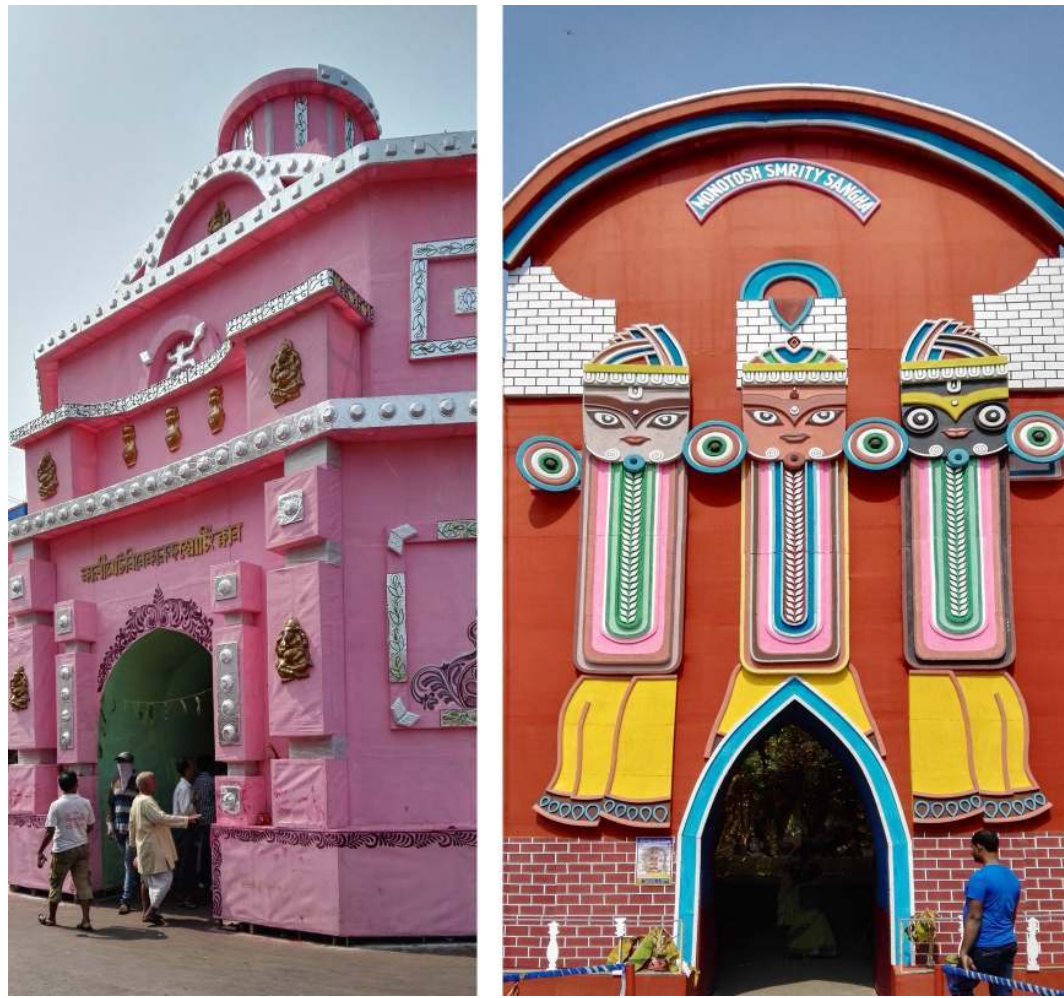

Source and copyright: ( ) Federico De Matteis.

The exuberance of the pandals is underscored by the generous use of brilliant colors, a constituent part of the Indian aesthetic ecology, that in Kolkata also acquires political significance (Sur, 2017). Some larger installations extend beyond the mere building, invading surrounding streets with arches, gates, canopies and other features that provide eloquent ceremonial access to the temple's interior. 
Illustration 7: Decorated access path to a pandal.

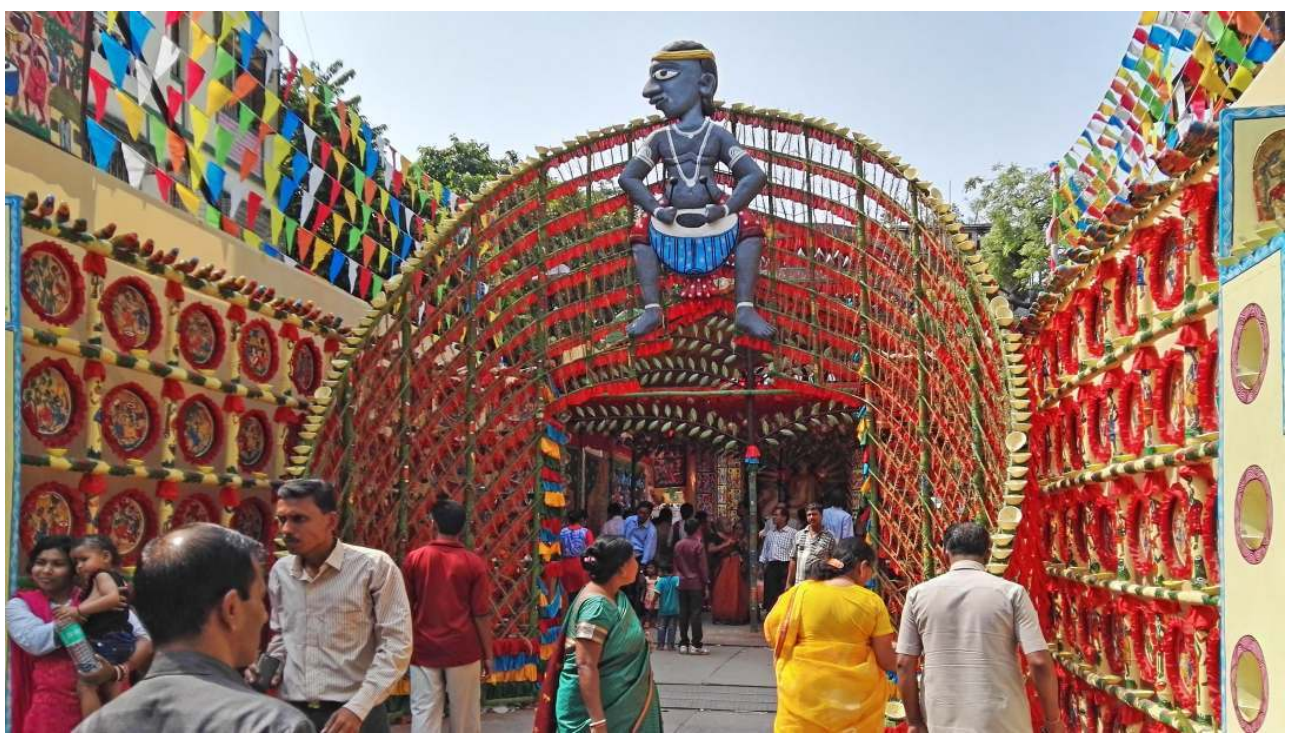

Source and copyright: @ F Federico De Matteis.

33 The variety of sizes, forms, styles, siting and construction of the pandals leaves little space for constant typological features. One spatial condition remains however stable: the frontality of the statue complex, that is almost invariably located opposite the entrance and against a closed wall, so that a clear frontal relationship is established between the visitors and the effigies of Durga and her following. The Goddess is placed in an elevated position, her back protected by a niche, with dramatic lighting emphasizing the plastic dynamism of the divine bodies.

Illustration 8: The Durga statue complex hosted in a niche.

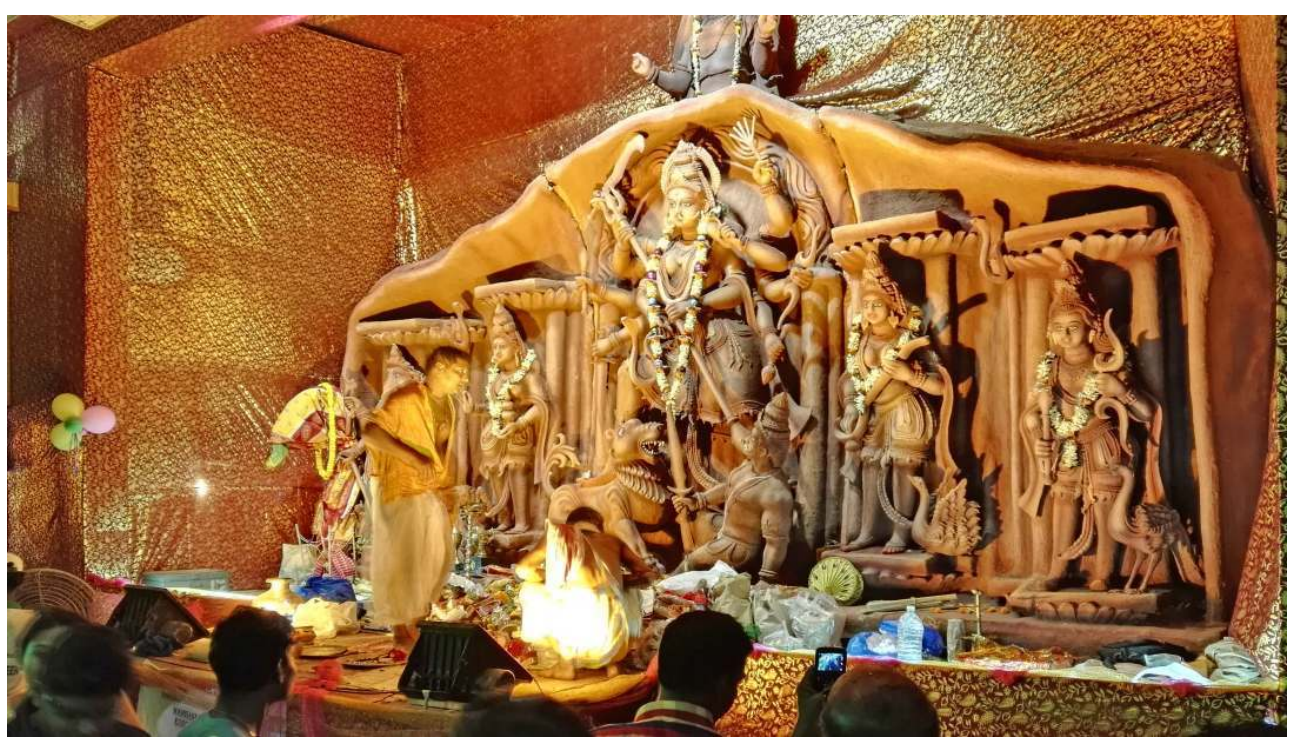

Source and copyright: (c) Federico De Matteis.

34 As the centerpiece of the entire celebration, the Durga statues revered during the puja are among the most interesting objects of Bengali craftsmanship. In the Kumartuli neighborhood, on the northern bank of the Hooghly river, a maze of streets and alleys 
hosts the community of workers that are engaged year-round in the production of clay figures for Durga puja and various other festivals, such as Kali puja, celebrated about three weeks later, or Saraswati puja in January. Statues have a supporting structure of tied straw and are plastered with clay sourced from the nearby river.

Illustration 9: Clay statue craftsmanship in Kumartuli: the straw structure of a Saraswati figure, and a Kali before painting.
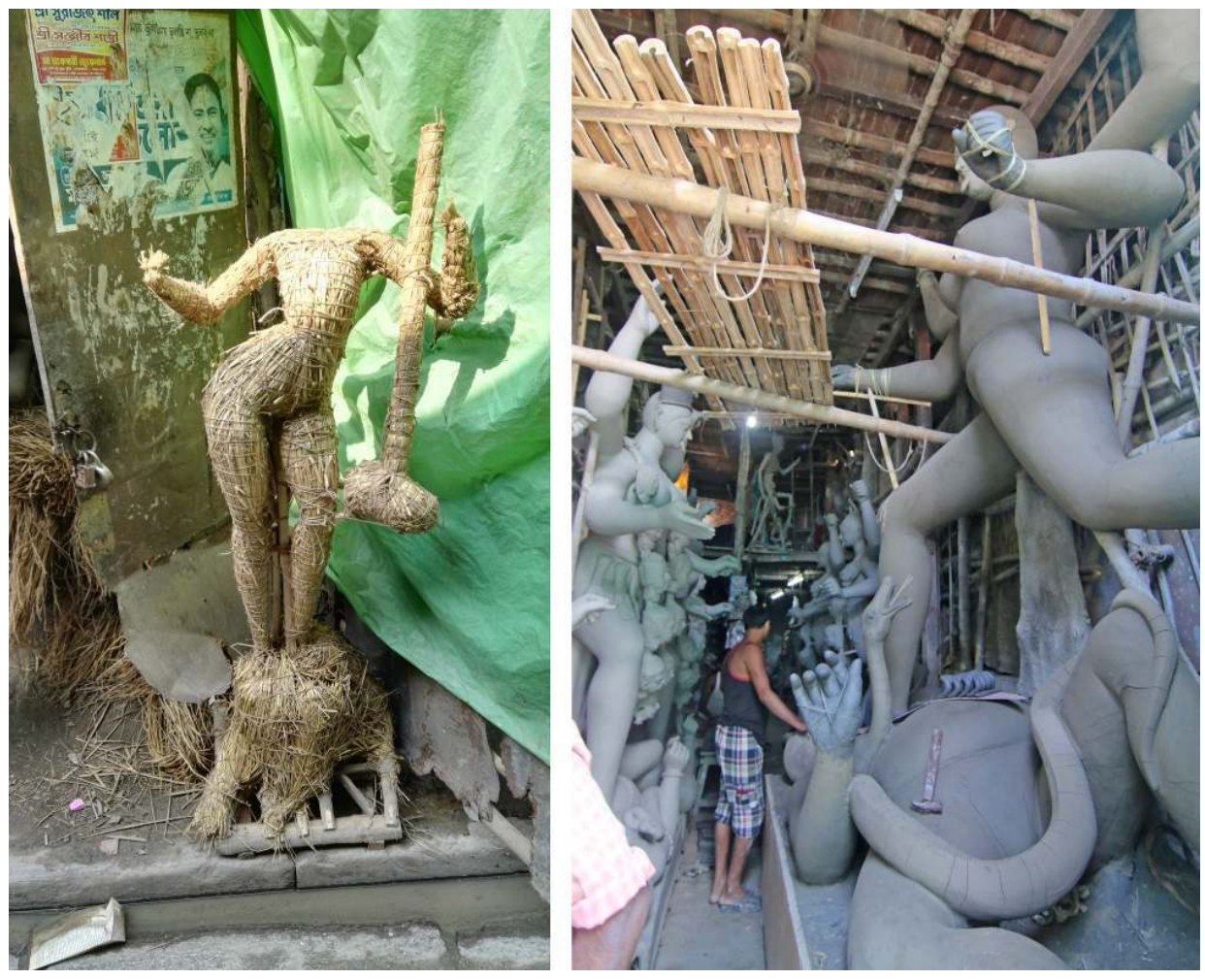

Source and copyright: @ Federico De Matteis.

Illustration 10: Clay statue craftsmanship in Kumartuli: painting of Kali statues during the days of Durga puja.

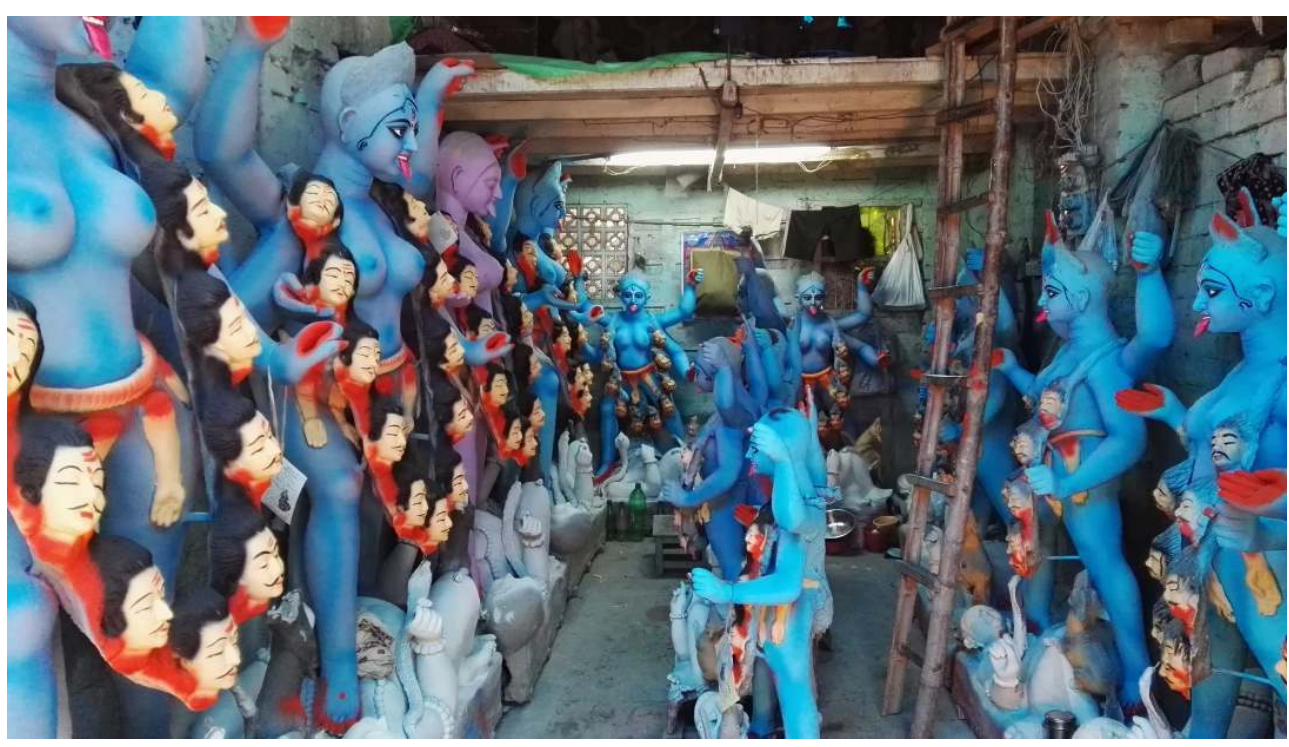

Source and copyright: (c) Federico De Matteis. 
The industry provides a livelihood to hundreds of people, from sculptors to painters, tailors and decorators, and the finished effigies often attest to their makers' exceptional skills. Kumartuli craftsmen produce most of the puja's statues, adopting the same wellestablished technique, with exceptions that include a wide section of India's deeply rooted artisanal tradition.

Illustration 11: A straw Durga statue complex.

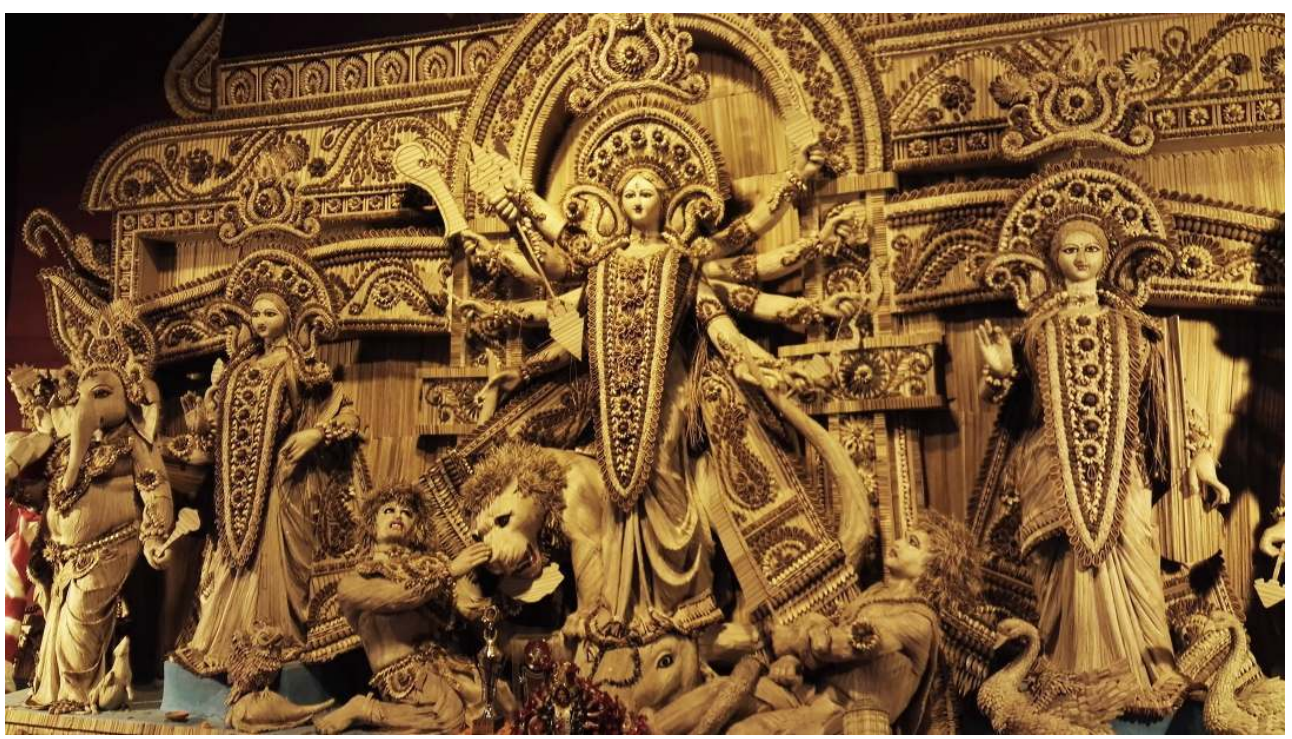

Source and copyright: () Federico De Matteis.

The presence of the pandals, their location within the urban fabric, and their architectural attributes give way to a stark modification of the city's ambiance. Usual vistas and thoroughfares are occluded by the presence of the incongruous marquees, creating new temporary cityscapes. Ritual chanting and recorded music from individual structures flows into the surrounding streets and merges between adjacent celebration sites, overlapping with the soundscape of Kolkata's ongoing bustle. The brilliant colors of the pandals contrast with the duller chromatism of the city's buildings and are synesthetically perceived as a vibrance that collectively affects the swarming crowds of devotees and visitors (Pérez-Gómez, 2016, p. 145).

Durga puja is not a religious festival alone, having gained increasing ground as a touristic event drawing vast numbers of visitors from near and far. Pandal-hopping, supported by maps provided by the Kolkata Police and a trove of Internet resources, is a favorite activity of visitors, who follow bucket lists of each year's best pujas. The presence of this festive crowd is no minor generator of the Durga puja atmosphere, echoing Sigfried Kracauer's description of metropolitan masses:

The bearer of the ornaments is the mass and not the people, for whenever the people form figures, the latter do not hover in midair but arise out of a community. A current of organic life surges from these communal groups - which share a common destiny - to their ornaments, endowing these ornaments with a magic force and burdening them with meaning to such an extent that they cannot be reduced to a pure assemblage of lines. (Kracauer, 1995, p. 76)

The multitude of visitors is at once a cause and effect of Kolkata's atmosphere during Durga's festival. The subjects' felt bodies collectively resonate with the perceptual 
encounter with spatial presences such as colors, sounds, music, and the corporeal dynamic of the vast crowd itself. If we consider that "emotions are atmospheres poured out spatially that move the felt [...] body" (Schmitz et al., 2011, p. 247), then they become available to all who are partaking in the situation - Durga worshippers, purohitas, local residents, foreign visitors - affording a certain affective movement. A form of cooperative embodiment animates the subjects' vital drive (Schmitz, 2011, p. 47), leading to the sense of excitement that can be felt in Kolkata's streets as all resonate with the collective movement. More than any individual element, I believe that it is this attunement that ultimately helps define the affective tonality of Kolkata's Durga puja: a Stimmung, or tone (Pérez-Gómez, 2016, p. 90) that is present in space, whose boundaries cannot be delimited, and can only be experienced in first person, exceeding a precise temporal frame, with the feeling lingering on until Kali puja or Divali (Rodrigues, 2003, p. 67), when Durga has returned to the mountains and the pandals have been dismounted.

\section{The Goddess is present}

In half-light, we see a snake where there is only a rope: sensible reality exists just as much as that snake. (Zolla, 1995, p. 83, author's translation'1).

During the rite that invokes Goddess Durga and gives her a temporary abode in the clay effigy, one important step performed by the purohita is the Caksur Dana - the giving of eyesight (Rodrigues, 2003, p. 167). The statue's three eyes are separately "activated" and kajal is applied to each, highlighting the Goddess's gaze. The apical character of this ritual moment stems from the centrality of reciprocation of sight - darshan - in Hindu worship practices:

Darshan is from the Sanskrit root drish, "to see." It refers to a most important element of Hinduism - the eye-to-eye contact between an iconic divinity or a divine personage and the devotee or worshipper. Darshan can by itself confer grace upon a seeker and result in spiritual benefit. So, Hindus eagerly visit temples as well as divine persons for darshan. If during a festival an icon is paraded through the streets, everyone vies to catch sight of it, to receive its glance and grace. No icon in the form of a person is considered an active divinity until the ritual opening of its eyes (Jones and Ryan, 2007, p. 119).

The pandals' architectural configuration is conceived to make this visual relationship between Goddess and worshipper as strong as possible. Durga's elevated position makes her forward-pointed gaze hover above the crowd, and the kajal-framed eyes create a powerful visual focus for anyone entering the tent. 
Illustration 12: Beholding the gaze of the Goddess.
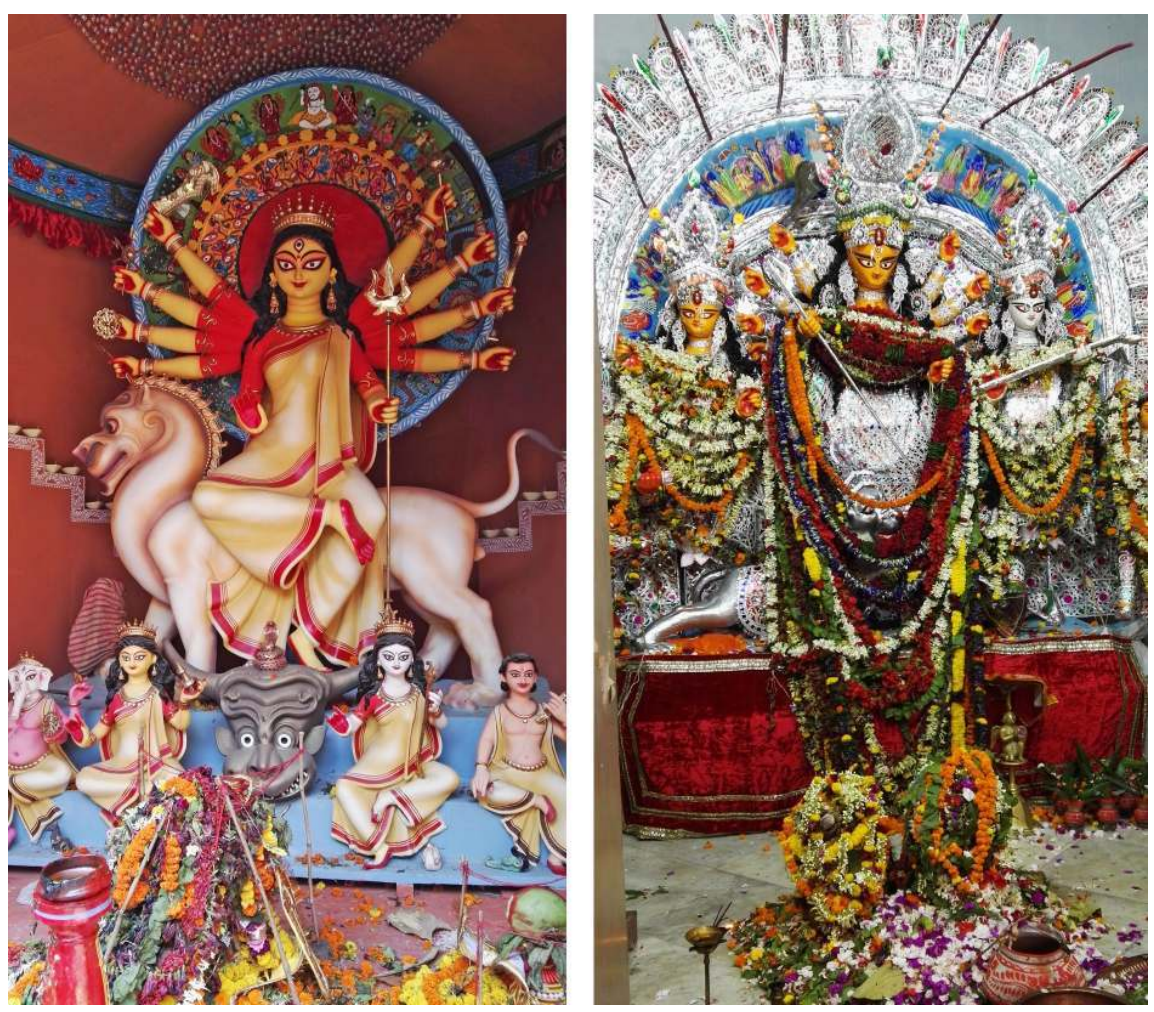

Source and copyright: @ Federico De Matteis.

As Schmitz notes, the exchange of gazes is a crucial part of corporeal communication, relying on visual perception, but is also experienced as a stirring of the subject's felt body (Schmitz, 2011, p. 31). The encounter with the Goddess, however, is not a balanced one, since the benevolent $\mathrm{Ma}$ - yet wrathful warrior Mahadevi - dominates the onlooker, whose corporeal contraction is relieved only by the enlightenment of a possible blessing received through darshan - the beholding of the divinity.

The situation installed inside the pandals may affect onlookers differently depending on each subject's religious convictions, but the ineffable feeling experienced there can hardly be neglected and is a constituent part of the puja's atmosphere. Goddess Durga is present through her incarnation in a clay statue, and the spatial arrangement of objects, people and immaterial agents acts as an ersatz of the supernatural presence itself. What emerges to the subject's perception is that numinous feeling that Rudolf Otto considers the grounding force of any religious experience, one that precedes and structures any further cognition of space and of the events unfolding there (Otto, 1926, p. 7). The exchange of gazes, therefore, is perhaps the tip of the iceberg, a corporeal interplay that takes place under the umbrella of that numinous sensation of demonic presence wherein the subject's felt body resonates, even before meeting Durga's eyes.

43 No matter how lay the urban staging of the festival may have become, or how distant from Hindu belief the visitor may be, the affective atmosphere generated within the pandals is an actual fact, one that bears only a limited connection to the physical constitution of the environment. Gernot Böhme so explains this twofold nature of reality:

We have again the necessity of making a distinction between physical reality [ Realität] and actual reality [Wirklichkeit]. [...] What must be distinguished is clear: on 
one side are things and the tangible human beings, and that what happens with them and between them: that is physical reality. On the other side, what they bring to appearance and the phenomenal events [...]: that can be described as actual reality, as phenomenal reality. What is crucial is that [...] phenomenal reality can be separated from physical reality, even isolated, and that there are social settings [...] that stabilize this separation between physical reality and actual reality for a given time, if not permanently (Böhme, 2001, pp. 118, author's translation ${ }^{2}$ ).

In this sense, the puja atmosphere can be considered as being staged more than real, a distinction, however, that in Böhme's view has limited impact on the subjects' experience of space (Böhme, 2013). What counts is that in the special time of Durga's festival the pujalaya, an otherwise negligible plot of urban land cordoned off by the ritualist, is temporarily elevated to an exceptional condition, where the subject may experience the numinous presence of the Goddess as a pervasive force: "God surrounds me like the physical atmosphere. He is closer to me than my own breath. In him - literally - I live and weave and am" (Schmitz, 1969, pp. 128, author's translation ${ }^{3}$ ).

A feeling of the space's exceptionality is pre-reflectively encountered as a presence that breaks from the norm, an instance of crisis that Mircea Eliade identifies as one of the fundamental moments of human experience, that religions have the power to address: "The religious solution not only resolves the crisis but at the same time makes existence 'open' to values that are no longer contingent or particular, thus enabling man to transcend personal situations and, finally, gain access to the world of spirit" (Eliade, 1987, p. 210). These supra-personal values thus become effused in space, and are atmospherically available as feelings to all those who are present: "With universal, Eliade does not intend a metaphysical, transcendental space, but the vital plenitude that is established once the crisis has blown up the private walling-in. One's own catastrophes and crises awake, provoke what it can mean to be here" (Baier, 2000, p. 102, author's translation ${ }^{4}$.

The state of exception caused by Durga's presence is eventually resolved at the end of the festival, when the Goddess's statues are carted away, returning the pandals' plots to their ordinary condition. 
Illustration 13: A Durga statue being carried to the Hooghly river.

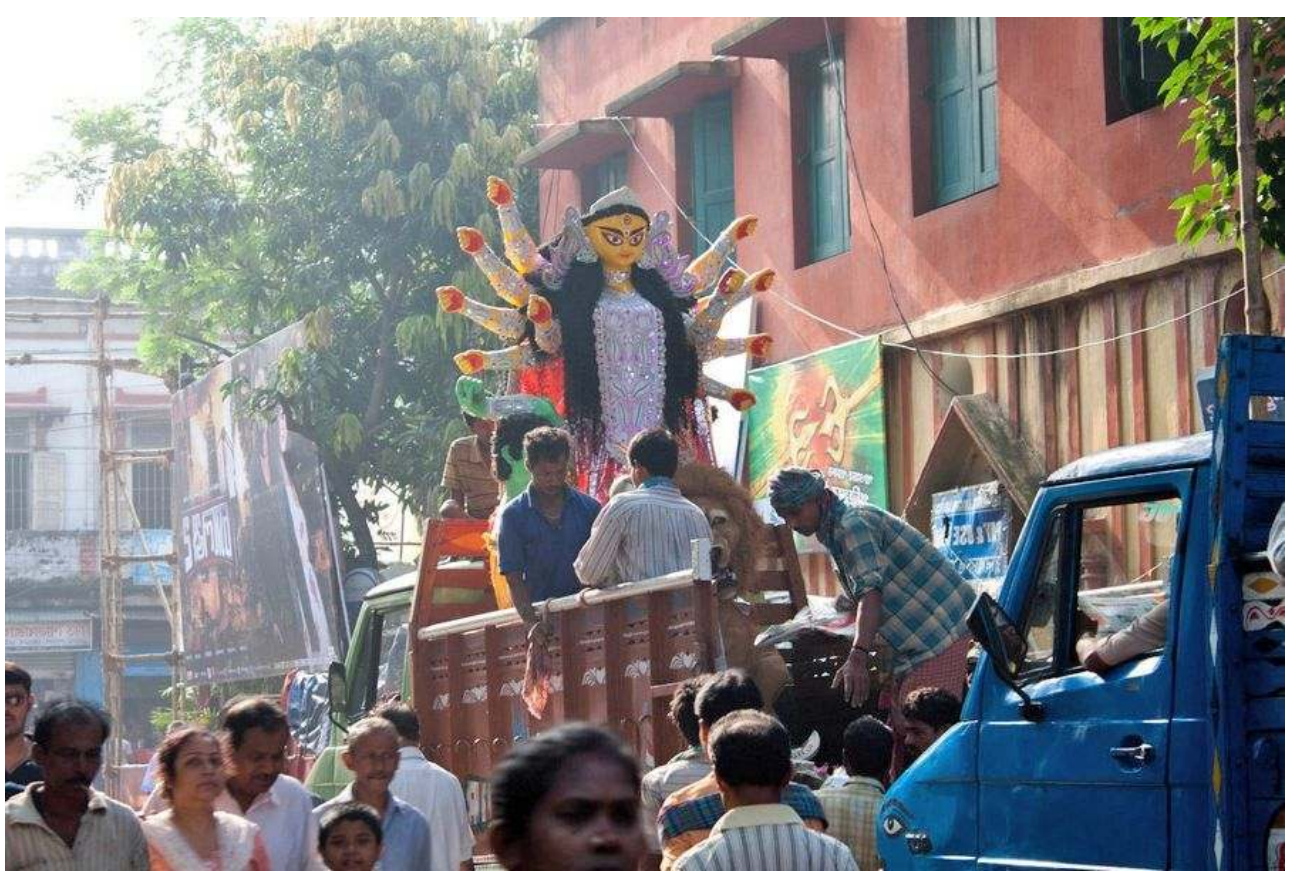

Source and copyright: @ Federico De Matteis.

The processions, festively accompanied by ceremonial drummers, lead the statues to the ghats, large flights of stairs facing the holy Hooghly river. There, the community or family that has hosted Durga bids one last farewell walking around the effigies, which is eventually brought to the shore and allowed to float away ${ }^{5}$, symbolizing her journey to return to her mountain abode. 
Illustration 14: Bidding farewell to Durga at Babu ghat.
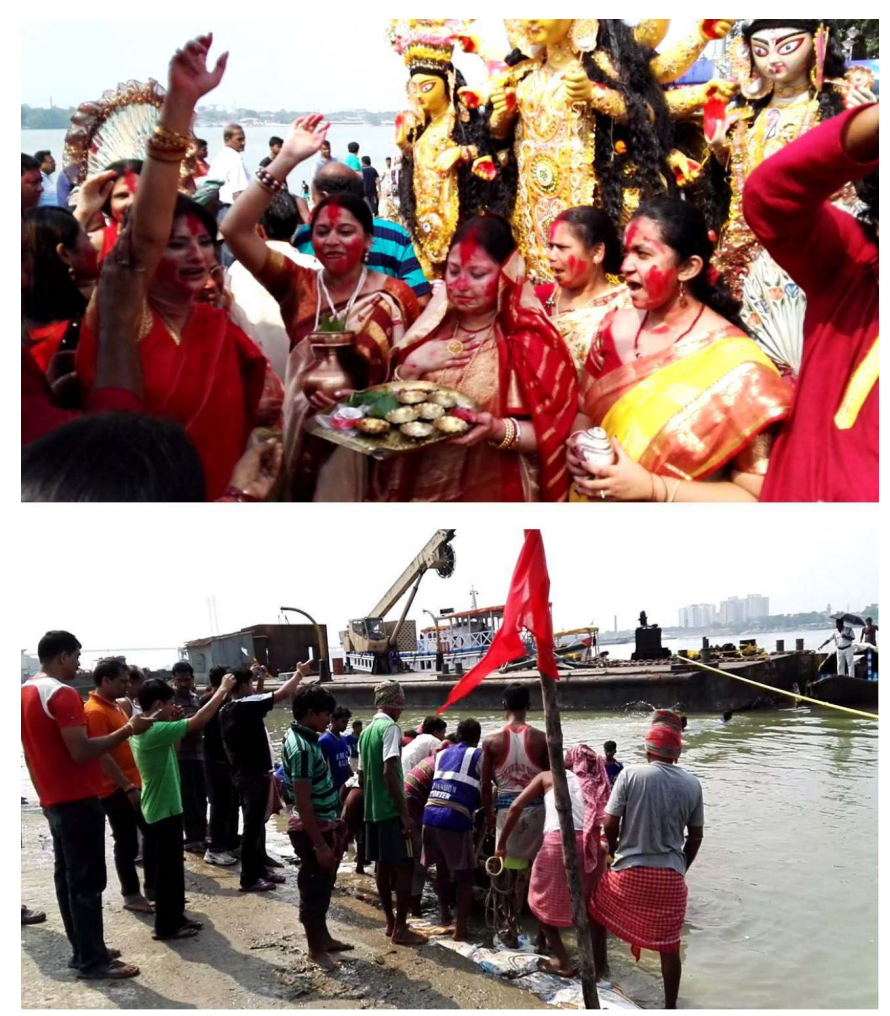

Source and copyright: (c) Federico De Matteis.

This final act of reverence signals the end of Durga puja, as the Goddess leaves her devotees, a departure also announcing the separation of the families that had come together to celebrate the holiday.

\section{The living heritage of Durga Puja}

Durga puja in Kolkata is an extraordinary religious and folk festival, with few comparable events to be found worldwide. Its deep-rooted tradition sustains the survival of a lively crafts industry in the city. Despite the increasing lay and commercial turn of the event, the strong religious sensibility of Bengali people anchors it to a solid mesh of rites, arts, urban practices and local customs. It is a precious instance of material culture, unhinged from a direct connection to physical objects, since all those used in the annual celebration of the Goddess are ritually destroyed, in a symbolization of the cycle of cosmic renewal.

Durga puja appears as a healthy, lively tradition in India, yet as previous history well shows, at times these manifestations of culture are more fragile than expected. Although it seems to have been "adopted" by the market economy, that leverages on its popularity as an advertising tool, the festival inevitably suffers from the increasing modernization that, in India as in any other emerging country, jeopardizes the survival of traditional culture. The mesh of social and economic relations that underlies the festival's survival local communities, family ties, the skills and livelihood of Kumartuli craftsmen, corporate sponsorship, municipal government, etc. - are all necessary to uphold a complex process encompassing a wide variety of collective and individual interests. Severing just one of those ties - something that can happen simply by the onset of some awkwardly thought- 
out regulation - may spark a chain reaction leading to the loss or deep transformation of the festival's character. Beyond its religious relevance, Durga puja in Kolkata is a big fact: a popular festival for families, a tourist attraction and a salient part of the city's identity, featured in literature and contemporary film ${ }^{6}$. But the West Bengal capital is also a megalopolis with its fair share of problems, and the festival must survive within this complicated urban framework.

51 Yet, beyond the material culture and the extant mesh of relations, what deserves attention as constituent part of heritage is the very affective space of the festival, the ambiance that I have described in these pages. Like all immaterial heritage, it is hinged to human life as much as to places, and it cannot be protected by being enshrined in a vitrine as one could do with a statue or a vase. Each year, the return of Goddess Durga brings about the re-enactment of emotions, and anyone experiencing them through his presence at the puja celebration partakes in a feeling that is, in a way, archaeological, having been felt cyclically for hundreds of years, albeit by different subjects. Manifestations such as Durga puja thereby overcome the "clause of subjectivity", implicating that the emotional landscape staged during the festival precedes a specific subject and is collectively available for anyone (Sørensen, 2015). At the same time, the affective space of the puja is a fundamental part of Kolkata's collective memory, since everyone who has experienced it at least once knows what it is like to be there. Affective spaces emerge from situations that comprise the material and the immaterial, corporeal practices and demonic presences; but ultimately, they are the only way of describing the situation as a whole, without reducing it to its constituent parts and losing that sense of continuity that underlies spatial experience.

\section{BIBLIOGRAPHY}

Amin, Ash. 2008. Collective culture and urban public space. City. vol 12, n 1, p. 5-24. https:// doi.org/10.1080/13604810801933495

Anderson, Ben. 2009. Affective atmospheres. Emotion, Space and Society. vol 2, p. 77-81. https:// doi.org/10.1016/j.emospa.2009.08.005

Baier, Franz Xaver. 2000. Der Raum : Prolegomena zu einer Architektur des gelebten Raumes. Cologne: König.

Bhattacharya, Tithi. 2007. Tracking the Goddess: religion, community, and identity in the Durga Puja ceremonies of Nineteenth-century Calcutta. The Journal of Asian Studies. vol 66, $\mathrm{n}^{\circ} \mathrm{4}, \mathrm{p}$. 919-962. https://doi.org/10.1017/S0021911807001258

Böhme, Gernot. 2001. Aisthetik : Vorlesungen über Ästhetik als allgemeine Wahrnehmungslehre. Munich: Fink.

Böhme, Gernot. 2013. The art of the stage set as a paradigm for an aesthetics of atmospheres. Ambiances [online]. Available online at: https://journals.openedition.org/ambiances/315

Böhme, Gernot. 2017. Atmospheric architectures : The aesthetics of felt spaces. London: Bloomsbury. 
Correa, Charles. 2011. The public, the private, and the sacred. In: Hejduk, Renata \& Williamson, Jim (eds.). The religious imaginations in modern and contemporary architecture. London and New York: Routledge. p. 103.

De Matteis, Federico. 2018. The city as a mode of perception. Corporeal dynamics in urban space. In: Aletta, Francesco \& Xiao, Jieling (eds.). Handbook of research on perception-driven approaches to urban assessment and design. Hershey: IGI Global. p. 438-457.

Eisenlohr, Patrick. 2018. Suggestions of movement: voice and sonic atmospheres in Mauritian Muslim devotional practices. Cultural Anthropology. vol 33, p. 32-57. https://doi.org/10.14506/ ca33.1.02

Eliade, Mircea. 1987. The sacred and the profane: The nature of religion. New York: Harcourt, Brace \& World.

Gandy, Matthew. 2017. Urban atmospheres. Cultural Geographies. vol 24, n 3, p. 353-374. https:// doi.org/10.1177/1474474017712995

Geertz, Clifford. 1973. The interpretation of cultures. New York: Basic Books.

Ghosh, Anjan. 2009. Contested spaces: Puja and its publics in Kolkata. Kolkata: Centre for Studies in Social Sciences, Calcutta.

Griffero, Tonino. 2013. The atmospheric "skin" of the city. Ambiances [online]. Available online at: https://doi.org/10.4000/ambiances.399

Griffero, Tonino. 2014. Atmospheres : Aesthetics of emotional spaces. Farnham: Ashgate.

Jones, Constance \& Ryan, James D. 2007. Encyclopedia of Hinduism. New York: Facts on File.

Kiib, Hans; Marling, Gitte \& Jespersen, Line Marie Bruun. 2017. The Orange feeling. Mood and atmosphere at Roskilde festival. Ambiances [online]. Available online at: https://doi.org/10.4000/ ambiances.829

Kracauer, Siegfried. 1995. The mass ornament : Weimar essays. Cambridge: Harvard University Press.

Otto, Rudolf. 1926. Das Heilige. Gotha: Leopold Klotz.

Pérez-Gómez, Alberto. 2016. Attunement : Architectural meaning after the crisis of modern science. Cambridge: The MIT Press.

Rauh, Andreas. 2017. In the clouds: on the vagueness of atmospheres. Ambiances [online]. Available online at: https://doi.org/10.4000/ambiances.818

Rodrigues, Hillary. 2003. Ritual worship of the great goddess : The liturgy of the Durgā Pūjā with interpretations. Albany: State University of New York Press.

Runkel, Simon. 2018. Collective atmospheres. Phenomenological explorations of protesting crowds with Canetti, Schmitz, and Tarde. Ambiances [online]. Available online at: https:// doi.org/10.4000/ambiances.1067

Ryle, Gilbert. 1968. The thinking of thought. Saskatoon: University of Saskatchewan.

Scheler, Max. 1923. Wesen und Formen der Sympathie. Bonn: Friedrich Cohen.

Schmitz, Hermann. 1969. System der Philosophie III.2 : Der Gefühlsraum. Bonn: Bouvier.

Schmitz, Hermann. 2011. Der Leib. Berlin and Boston: De Gruyter. 
Schmitz, Hermann; Müllan, Rudolf Owen \& Slaby, Jan. 2011. Emotions outside the box-the new phenomenology of feeling and corporeality. Phenomenology and the Cognitive Sciences. vol $10, \mathrm{n}^{\circ} 2$, p. 241-259. https://doi.org/10.1007/s11097-011-9195-1

Sheets-Johnstone, Maxine. 2011. The primacy of movement. Amsterdam and Philadelphia: John Benjamins.

Sørensen, Tim Flohr. 2015. More than a feeling: towards an archaeology of atmosphere. Emotion, Space and Society. vol 15, p. 64-73. https://doi.org/10.1016/j.emospa.2013.12.009

Sur, Malini. 2017. The blue urban: colouring and constructing Kolkata. City. vol 21, n 5, p. 597-606. https://doi.org/10.1080/13604813.2017.1374785

Thibaud, Jean-Paul. 2011. The sensory fabric of urban ambiances. The Senses and Society. vol $6, \mathrm{n}^{\circ}$ 2, p. 203-215. https://doi.org/10.2752/174589311X12961584845846

Thibaud, Jean-Paul. 2015. The backstage of urban ambiances: When atmospheres pervade everyday experience. Emotion, Space and Society. vol 15, p. 39-46. https://doi.org/10.1016/ j.emospa.2014.07.001

Thrift, Nigel. 2008. Non-representational theory : Space / Politics | Affect. London and New York: Routledge.

Wober, Mallory. 1966. Sensotypes. Journal of Social Psychology. vol 70, p. 181-189.

Zolla, Elémire. 1995. Aure : I luoghi e i riti. Venice: Marsilio.

\section{NOTES}

1. Original text: "Nella penombra crediamo di vedere un serpente là dove c'è soltanto una corda: la realtà sensibile esiste quanto quel serpente."

2. Original text: "Wir treffen hier erneut auf die Notwendigkeit, zwischen Realität und Wirklichkeit zu unterscheiden. [...] Was aber unterschieden werden soll, ist klar. Auf der einen Seite die Dinge und die konkreten Menschen und das, was mit ihnen und unter ihnen geschieht: das sei Realität genannt. Auf der anderen Seite das, was sie zur Erscheinung bringen und das phänomenale Geschehen [...]: das sei als Wirklichkeit bezeichnet, nämlich als phänomenale Wirklichkeit. Beides kann zusammenhängen, und ihr Zusammenhang muß näher studiert werden. Entscheidend aber ist [...] daß die phänomenale Wirklichkeit von der Realität abgehoben, geradezu isoliert werden kann, und daß es soziale Settings [...] gibt, die diese Trennung von Realität und Wirklichkeit für eine Weile stabilisieren, wenn nicht auf Dauer stellen."

3. Original text: "Gott umgibt mich wie die physische Atmosphäre. Er ist mir näher als mein eigener Atem. In ihm - buchstäblich - lebe und webe und bin ich."

4. Original text: "Mit universell meint Eliade aber nicht einen metaphysischen, jenseitigen Raum, sondern die Lebensfülle, die sich einstellt, nachdem die Krise die private Einmauerung gesprengt hat. Die eigenen Katastrophen und Krisen rütteln wach, prozieren, was „da“-sein bedeuten kann".

5. Due to environmental concerns and the heavy pollution of the Hooghly, statues are today removed from the water just downstream of the ghats and disposed of on dry land.

6. Just to mention one, Sujoy Ghosh's widely popular 2012 film Kahaani is set during Kolkata's Durga puja, and the festival's celebrations and locations feature prominently in the storyline. 


\section{ABSTRACTS}

This paper provides a description of the Durga Puja religious festival that is held each autumn in Kolkata. During the ten days of the celebration, the Indian city is enriched by a multitude of temporary temples, where local communities come together for both religious and social gatherings. The colourful marquees host rituals and music, flooding urban space with a festive atmosphere that has become a hallmark of Kolkata, attracting large crowds of visitors and tourists who are interested in the folk festival and in its religious connotation. The description focuses on the emotional response to the transformed space, analyzing how the rituals performed in the temporary temples, and the urban and architectural features of the festival's instalment affect the visitors' corporeal feelings.

Cet article offre une description du festival religieux de Durga Puja qui a lieu chaque automne à Kolkata. Pendant les dix jours de la célébration, la ville indienne est enrichie par une multitude de temples temporaires, dans lesquels les communautés locales se retrouvent pour des rassemblements à la fois religieux et sociaux. Les chapiteaux colorés accueillent des rituels et de la musique, inondant l'espace urbain d'une atmosphère de fête qui est devenue une marque distinctive de Kolkata, attirant de larges foules de visiteurs et de touristes intéressés par le festival folklorique et par sa dimension religieuse. La description se concentre sur la réponse émotionnelle à l'espace transformé, analysant la manière dont les rituels se déroulent dans les temples temporaires, ainsi que l'effet des caractéristiques urbaines et architecturales de l'installation du festival sur le ressenti corporel des visiteurs.

\section{INDEX}

Mots-clés: Durga Puja, Kolkata, Festival religieux, Espace urbain, Espace affectif, Atmosphère urbaine, Ambiances, Architecture temporaire, Architecture religieuse Hindu

Keywords: Durga Puja, Kolkata, Religious Festival, Urban Space, Affective Space, Urban Atmospheres, Temporary Architecture, Ambiances, Hindu Religious Architecture

\section{AUTHOR}

\section{FEDERICO DE MATTEIS}

Dr. Federico De Matteis is an architect and Associate Professor at the University of L'Aquila, Italy. His research focuses on the affective and corporeal dimension of urban and architectural space, and on the relationship between design practices and emotional response.

Contact: federico.dematteis@univaq.it 